\title{
Neuroprotective Effect of Carica papaya Leaf Extract against Aluminium Toxicity: An Experimental Study on Cognitive Dysfunction and Biochemical Alterations in Rats
}

\author{
Kalluri Hima Bindhu', Arumugam Vijayalakshmi ${ }^{2, *}$ \\ 1Department of Pharmacology, Kakatiya University, Warangal, Andhra Pradesh, INDIA. \\ ${ }^{2}$ School of Pharmaceutical Sciences, Vels Institute of Science, Technology and Advanced Studies (VISTAS), Pallavaram, Chennai, \\ Tamil Nadu, INDIA.
}

\begin{abstract}
Objective: To study the protective role of alcoholic leaf extract of Carica papaya in aluminium induced cognitive dysfunction and oxidative damage in albino rats and to explore the neuroprotective effect of Carica papaya represented by behaviour and memory tests. Methods: The study was carried out for a period of 42 days (6 weeks) in aluminium chloride induced model. Behavioural assessment is done using Rota rod apparatus and Elevated plus maze and biochemical parameters from brain homogenate like acetyl cholinesterase (AchE) activity, Total protein, Lipid peroxidation (MDA), Super oxide dismutase (SOD), Catalase, Glutathione Reductase (GR) were estimated. Male Wistar rats (30) were divided into 5 groups of 6 rats each. Group I received normal saline. Group II were administered orally with aluminium chloride $(100 \mathrm{mg} / \mathrm{kg})$. Group III received Rivastigmine $0.3 \mathrm{mg} / \mathrm{kg}$ body orally. Group IV and V were administered with alcoholic Carica papaya leaf extract 200 and $400 \mathrm{mg} / \mathrm{kg}$ along with aluminium chloride of $100 \mathrm{mg} / \mathrm{kg}$ orally after $1 \mathrm{hr}$ interval. All the data was analysed using One-way ANOVA followed by Tukey's multiple comparison test. Results: Administration of alcoholic Carica papaya leaf extract $(200 \mathrm{mg} / \mathrm{kg}$ and $400 \mathrm{mg} / \mathrm{kg})$ showed significant $(P<0.001)$ increase in level of acetyl choline, significant $(P<0.001)$ reduction of total protein and significant $(P<0.001)$ increase in the level of SOD, Catalase and Glutathione reductase in a dose dependent manner when compared with positive control. positive control. Conclusion: This study demonstrates alcoholic Carica papaya leaf extract has a neuroprotective effect against aluminium induced behavioural changes.
\end{abstract}

Key words: Carica papaya, Neuroprotective, Alzheimer's disease, Aluminium chloride

\section{INTRODUCTION}

Alzheimer's is a degenerative and terminal disease for which there is no known cure. In its most common form, it effects individuals over 65 years old. Currently, there is no cure for Alzheimer's and no way to stop the underlying death of brain cells. But drugs and non-drug treatments may help with both cognitive and behavioural symptoms. Today, Alzheimer's is at the forefront of biomedical research, with $90 \%$ of what we know discovered in the last 20 years. ${ }^{1}$ Some of the most remarkable progress has shed light on how Alzheimer's disease affects the brain. Better understanding of its impact may lead to better ways to treat it. A comprehensive care plan for Alzheimer's disease involves Monitoring treatment effectiveness as the disease progresses, changing course and exploring alternatives as necessary and respecting individual and family goals for treatment and tolerance for risk. ${ }^{2}$

Carica papaya has been reported to have immense pharmacological and therapeutic activity. Various research works carried
Submission Date: 16-10-2018; Revision Date: 05-01-2019; Accepted Date: 24-04-2019

DOI: 10.5530/ijper.53.3s.111 Correspondence:

Dr. Arumugam Vijayalakshmi, (M. Pharm, Ph. D.),

Associate Professor, School of Pharmaceutical Sciences, VISTAS, Pallavaram, Chennai- 600117, Tamil Nadu, INDIA. Phone: +91-9176093990 E-mail: aviji_1975@rediffmail.com

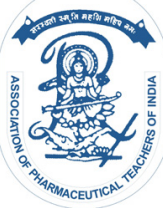

www.ijper.org 
out have proved it to be used in various diseases like Arteriosclerosis, hyperglycaemia, antiviral, anti-inflammatory activity. The leaf juice has proved to have an effective treatment in Dengue fever. ${ }^{3}$ The observed antiinflammatory and anti-malarial activities of leaf extracts have been attributed to quinones and steroids. ${ }^{4}$

Aluminium is a non-redox active metal which is capable of increasing the cellular oxidative milieu by potentiating the pro-oxidant properties of transition metals such as iron and copper., ${ }^{5,6}$ It leads to progressive deterioration of mitochondrial function which culminates into excessive free radical generation eventually resulting in DNA damage, nitration of protein residues and lipid peroxidation. Carica papaya extract indicated significant cytoprotective effects against glutamate triggered cell death in HT22 cells. Based on this background, present study was designed to investigate the neuro-protective effect of alcoholic Carica papaya leaf extract against aluminium induced cognitive impairment and associated oxidative damage in rats.

\section{MATERIALS AND METHODS}

\section{Plant Material}

The Carica papaya leaf (700 g) was collected from Jangareddygudem, in Andhra Pradesh, India. The sample was then shade dried till constant weight obtained. The leaf was identified and authenticated by Prof. Vatsavaya S. Raju, M.Sc., Ph.D., D.A.S., FBS, FIAT and the sample was deposited in the Herbarium, Department of Botany, Kakatiya University, Warangal, A.P., with specimen voucher number 1887. The species is known as "boppaya" locally and globally as 'papaya'.

\section{Chemicals}

Aluminium Chloride (CDH, India), Rivastigmine (Novartis Co., Cairo, Egypt), Ethanol 90\%, Acetyl thiocholine iodide, DTNB reagent, tris buffer, biuret reagent, trichloro acetic acid, potassium phosphate buffer, O-dianisidine solution, potassium dihydrogen and dipotassium hydrogen phosphate, sodium phosphate buffer, xylene, hematoxylin, eosin stain.

\section{Animals}

Healthy adult male albino rats of Wistar strain weighing $(200-230 \mathrm{~g})$ were selected from Albino research training institute, Hyderabad, India and were used for the experiment. The animals were acclimatized to standard laboratory conditions with temperature $\left(25 \pm 2^{\circ} \mathrm{C}\right)$ and fed with standard animal pellet feed (Hindustan lever limited), ad libitum. The protocol was approved by Institutional Animal Ethics Committee (IAEC) constituted for the purpose of animal experimentation as per CPCSEA guidelines (Reg.No. ARTI/CPCSEA/0035-2013), with Approval no: (CPCSEA/IAEC/EXP/25/50/2013/ EXP-35) for the care and use of animals.

\section{Extraction of Plant Material}

The leaves $(5-6 \mathrm{~kg})$ were cleaned and the size was reduced by cutting in to small parts and were shade dried. They were coarsely powdered with the help of a blender $(300$ $\mathrm{g})$. The coarse powder $(250 \mathrm{~g})$ of the leaves was then exhaustively extracted with $500 \mathrm{~mL}$ of Ethyl alcohol using Soxhlet apparatus. The extract was concentrated by distilling the solvent and preserved under refrigeration for further studies. The obtained semi-solid dried extract was further subjected to various chemical tests to detect the presence of different phyto-constituents. ${ }^{7}$

\section{Acute Toxicity Study}

As per the OECD guidelines 423, the acute toxicity of the alcoholic extract of Carica papaya leaf was tested on different groups of 10 rats. $^{8}$ Each receiving different doses of 50, 100, 200, 400, 800, 1000 and $2000 \mathrm{mg} /$ $\mathrm{kg}$ body weight. The number of deaths and behavioural changes were observed in each group and recorded with in $48 \mathrm{~h}$. Up to $2000 \mathrm{mg} / \mathrm{kg}$, there were no signs of toxicity and mortality. Based on these studies 200 and $400 \mathrm{mg} / \mathrm{kg}$ of alcoholic Carica papaya leaf extract were selected for the present experimental study.

\section{Allotment of Animals and Drug Treatment}

Male Wistar rats (30) were divided into 5 groups of 6 rats each by computerized randomization method.

Group I served as normal control and received normal saline. Group II were administered with aluminium chloride at a dose of $100 \mathrm{mg} / \mathrm{kg}$ through oral route by dissolving in normal saline. Group III was administered with standard drug rivastigmine orally by dissolving in normal saline at a dose of $0.3 \mathrm{mg} / \mathrm{kg}^{7}{ }^{7}$ Group IV and V were administered with test drug alcoholic Carica papaya leaf extract 200 and $400 \mathrm{mg} / \mathrm{kg}$ along with aluminium chloride at $100 \mathrm{mg} / \mathrm{kg}$ bodyweight through oral route. The study was carried out for a period of 42 days $(6$ weeks). The drug was administered orally $1 \mathrm{~h}$ after aluminium chloride administration.

\section{Behavioural Assessment ${ }^{9}$}

On the day 0,21, 42 behavioural assessments was carried out for Elevated plus Maze and rotarod apparatus.

\section{Muscle Relaxant Property by using Rota rod Method}

Rota-rod apparatus was turned on by selecting an appropriate speed $(20-25 \mathrm{rpm})$. The animals were placed one by one in to several compartments and the 'fall off time' were noted when the rat falls from the rotating rod. A normal group of rats generally falls off within 3-5 mins. Later the treated groups were followed by noting the fall off time.

\section{Performance on Elevated Plus Maze}

The elevated plus maze consisted of two opposite black open arms $(50 \mathrm{~cm} \times 10 \mathrm{~cm})$, crossed with two closed walls 
of the same dimensions with $40 \mathrm{~cm}$ high walls. The arms were connected with a central square of dimensions 10 $\mathrm{cm} \times 10 \mathrm{~cm}$ the entire maze was placed $50 \mathrm{~cm}$ high above the ground. Acquisition of memory was tested on day 20 from the start of aluminium chloride administration. Rats were placed individually at one end of the open arm facing away from the central square. The time taken by the animal to move from the open arm to the closed arm was recorded as the Initial Transfer Latency (ITL). Retention of memory was assessed by placing the rat in an open arm and the retention latency was noted on day 21 and day 42 respectively.

\section{Biochemical Assessment}

Biochemical tests were conducted $24 \mathrm{hr}$ after the last behavioural test. The animals were sacrificed by decapitation; the brains were removed, weighed and kept on ice. A $10 \%(\mathrm{w} / \mathrm{v})$ tissue homogenate was prepared in $0.1 \mathrm{M}$ phosphate buffer ( $\mathrm{pH}$ 7.4) using Teflon tissue homogenizer at $1000 \mathrm{xg}$ for $20 \mathrm{~min}$ at $4^{\circ} \mathrm{C}$. The homogenate so obtained was used for the assessment of biochemical parameters like Acetyl cholinesterase (AchE), protein, Lipid peroxidation (MDA), Super Oxide Dismutase (SOD), Catalase, Glutathione Reductase (GR) activities.

\section{Histopathological Examination}

The whole brain of the rat was taken and divided in to two sections, the first portion was used for biochemical estimation and the second portion of the brain was fixed in formalin buffer $(10 \%)$ for $24 \mathrm{hr}$. The brains are washed in tap water and then dehydrated using serial dilutions of alcohol. Specimens are cleared in xylene and embedded in paraffin in a hot air oven at $56^{\circ} \mathrm{C}$ for 24 hr. Paraffin bees wax blocks are prepared for sectioning at $4 \mathrm{~mm}$ using a microtome. The obtained tissues sections are collected on glass slide deparaffinised, stained with haematoxylin and eosin stains for histopathological examination using a light microscope.

\section{Statistical Analysis}

All the data were expressed as Mean \pm SEM and were analyzed by One-way ANOVA followed by Tukey's multiple comparison test as post hoc test. A ' $P$ ' value of $<0.001$ was considered as statistically significant. Data was analyzed by using Graph Pad prism software.

\section{RESULTS AND DISCUSSION}

In the present study the neuroprotective effect of alcoholic Carica papaya leaf extract was investigated in aluminium chloride induced Alzheimer's disease.

\section{Preliminary Phytochemical Screening}

The percentage yield of ethanol extract of Carica papaya was found to be $3.60 \% \mathrm{w} / \mathrm{w}$. The qualitative phytochemical analysis of the extract showed the pres- ence of carbohydrates, proteins, flavonoids, alkaloids, steroids, tannins and minerals.

\section{Acute Toxicity Study}

The purified and dried yield of alcoholic Carica papaya leaf extract was subjected for the acute toxicity study to determine the therapeutic dose using albino rats in controlled environment. Acute toxicity studies were performed according to the OECD 423 guidelines. The extract was administered through oral route to different groups of rats using oral feeding needle (22gauge). No deviation from normal behavioural pattern was observed. Observation was done continuously for 14 days and mortality was not observed in any of the drug treated group, hence it was confirmed that the test drug alcoholic $C P$ leaf extract is practically nontoxic in normal rats and fall under the category of class $\mathrm{V}$ drugs, according to OECD guidelines. $1 / 10^{\text {th }}$ of dose was considered as therapeutic dose and to identify the dose dependent action the $200 \%$ of therapeutic dose was considered as maximum dose for further pharmacological evaluation in animal model. Lower dose $(200 \mathrm{mg} / \mathrm{kg})$ and higher dose $(400 \mathrm{mg} / \mathrm{kg})$.

\section{Behavioural and Biochemical Assessment}

As aluminium chloride induced Alzheimer's disease generally preferred appropriate model for the early onset of senile dementia, we used the above model for disease induction. ${ }^{10,11} \mathrm{~A}$ number of models have been used for the study of Alzheimer's disease. In the present study of Aluminium chloride administration proved synergistic effects on accelerating the development and progression of Alzheimer's disease. Long term oral administration of Aluminium chloride for 42 days caused Alzheimer's disease in rodent model which involves the pathological, neurochemical, behavioural and biochemical alterations in the levels of acetylcholinesterase activity, Protein, Catalase, SOD, MDA, GH.

In the elevated plus maze, on the $20^{\text {th }}$ day the Initial Transfer Latency (ITL) was taken and there was no significant variation. Normal control $\left({ }^{*} p<0.001\right)$ and Carica papaya leaf extract treated $(200 \mathrm{mg} / \mathrm{kg})$ and $(400 \mathrm{mg} / \mathrm{kg})$ rats entered closed arm quickly and the mean Retention Latencies ( $1^{\text {st }}$ RTL and $2^{\text {nd }}$ RTL) to enter the closed arms on day 21 and 42 were shorter when compared to ITL. Aluminium chloride treated $\left({ }^{\phi} p<0.001\right)$ rats showed no variation in mean retention latency on $21^{\text {st }}$ and $42^{\text {nd }}$ day when compared to pretrained animals ITL on $20^{\text {th }}$ day (Table 1). This shows cognitive impairment of aluminium chloride treated animals.

In rota rod apparatus the fall off time is been recorded for each group of animals and is known to observe on $20^{\text {th }}$ day as initial fall off time. Standard $\left({ }^{a} p<0.001\right)$, Carica papaya leaf extract $(200 \mathrm{mg} / \mathrm{kg})$ and $(400 \mathrm{mg} / \mathrm{kg})$ showed decrease in fall off time on the $21^{\text {st }}$ day and $42^{\text {nd }}$ day after training. Positive control $\left(\beta^{\infty}<0.001\right)$ showed an increase in fall of time when compared to initial fall 
off time (Table 2). This shows neurological deficit elicits motor in co-ordination. The results of our study indicate that chronic administration of aluminium chloride results in progressive deterioration of spatial memory and motor in co-ordination elicited through behavioural parametric estimations in elevated plus maze and rota rod paradigms.

\section{Biochemical Assessment}

In the present study, chronic administration of aluminium chloride resulted in marked oxidative stress as indicated by increase in lipid peroxidation, decrease in reduced glutathione levels, catalase and superoxide dismutase and glutathione- $S$-transferase activity in the positive control group animals. This could be due to the reduced axonal mitochondria turnover, disruption of Golgi and reduction of synaptic vesicles induced by aluminium treatment which results in release of oxidative products like malondialdehyde, carbonyls, peroxynitrites and enzymes like superoxide dismutase within the neurons. ${ }^{12}$ Administration of alcoholic $C P$ leaf extract $(200 \mathrm{mg} / \mathrm{kg}$ and $400 \mathrm{mg} / \mathrm{kg}$ ) proved a marked increase in level of acetyl choline compared to positive control $\left({ }^{\beta}<<0.001\right)$. Aluminium chloride administered rats showed a great decline in acetyl choline levels when compared to normal control $(* p<0.001)$. This proves that $C P$ leaf extract showed an evidence for neuroprotection (Table 3).
Administration of alcoholic Carica papaya leaf extract $(200 \mathrm{mg} / \mathrm{kg}$ and $400 \mathrm{mg} / \mathrm{kg}$ ) showed significant reduction of total protein and significant increase in the level of SOD, Catalase and Glutathione reductase in a dose dependent manner when compared with positive control (Table 3).

Chronic administration of aluminium chloride showed marked increase in free radical generation and rise in MDA levels causing lipid peroxidation when compared to normal control $\left({ }^{*} p<0.001\right)$ and treatment with alcoholic CP leaf extract $(200 \mathrm{mg} / \mathrm{kg})$ and $(400 \mathrm{mg} / \mathrm{kg})$ showed decrease in levels of MDA compared to positive control $(\$ p<0.001)$

Free radicals have been implicated in alzheimer's and reperfusion-induced neuronal injury. ${ }^{13}$ Free radicals promote lipid peroxidation which results in the alteration in permeability and fluidity of membrane. ${ }^{14}$ Reactive Oxygen Species (ROS) Produces Malondialdehyde (MDA), an end product of lipid peroxidation. MDA reacts with thiobarbituric acid and is thus estimated as Thiobarbituric Acid Reactive Substances (TBARS). Therefore, in the present study MDA was estimated using TBARS assay to estimate the extent of ROS formation. It is well reported that overproduced free radicals are detoxified by endogenous antioxidants. Glutathione is considered a central component in the antioxidant defences of cells. It acts both to directly detoxify ROS and as a substrate for various peroxidises. ${ }^{15}$ Aluminium is a potent

\begin{tabular}{|c|c|c|c|c|}
\hline Groups & Treatment & $\begin{array}{c}\text { Initial } \\
\text { transfer latency }\end{array}$ & $\begin{array}{l}\text { Transfer latency } \\
1^{\text {st }} \text { trial }\left(21^{\text {st }} \text { day }\right)\end{array}$ & $\begin{array}{l}\text { Transfer latency } \\
2^{\text {nd }} \text { trial }\left(\mathbf{4} 2^{\text {nd }} \text { day }\right)\end{array}$ \\
\hline Group I & Vehicle only & $61.90 \pm 0.55$ & $18.02 \pm 0.22$ & $16.02 \pm 0.44$ \\
\hline Group II & $\mathrm{AlCl}_{3}(100 \mathrm{mg} / \mathrm{kg})$ & $66.13 \pm 1.04$ & $79.98 \pm 1.11^{*}$ & $74.98 \pm 0.92^{*}$ \\
\hline Group III & Rivastigmine $(0.3 \mathrm{mg} / \mathrm{kg})$ & $64.00 \pm 0.63$ & $19.48 \pm 0.41^{\$}$ & $16.05 \pm 0.47^{\$}$ \\
\hline Group IV & CP leaf extract $(200 \mathrm{mg} / \mathrm{kg})$ & $66.73 \pm 0.61$ & $47.34 \pm 1.32^{\$ a}$ & $42.84 \pm 1.02^{\mathrm{sa}}$ \\
\hline Group V & $\mathrm{CP}$ leaf extract $(400 \mathrm{mg} / \mathrm{kg})$ & $67.12 \pm 0.77^{c}$ & $32.59 \pm 0.60^{\text {\$c }}$ & $27.09 \pm 1.79^{\$ c}$ \\
\hline
\end{tabular}

Values were expressed as Mean \pm SEM of each group $(n=6)$ and were significant when done One-way ANOVA with Tukey's post hoc test. '*' $p<0.001$ when compared with normal, ' $\$$ ' $p<0.001$ with positive control, 'a' $p<0.001$ with standard.

\begin{tabular}{|c|c|c|c|}
\hline Groups & Treatment & $1^{\text {st }}$ trial (21 $1^{\text {st }}$ day) & $2^{\text {nd }}$ trial (42 ${ }^{\text {nd }}$ day) \\
\hline Group I & Vehicle only & $167.3 \pm 2.17$ & $142.7 \pm 5.10$ \\
\hline Group II & $\mathrm{AlCl}_{3}(100 \mathrm{mg} / \mathrm{kg})$ & $93.57 \pm 0.70^{*}$ & $85.91 \pm 1.96^{*}$ \\
\hline Group III & Rivastigmine $(0.3$ mg/kg) & $96.82 \pm 1.07^{\$}$ & $82.08 \pm 3.30^{\$}$ \\
\hline Group IV & CP leaf extract $(200 \mathrm{mg} / \mathrm{kg})$ & $123.0 \pm 0.98^{\$ a}$ & $110.8 \pm 1.66^{\S a}$ \\
\hline Group V & CP leaf extract $(400 \mathrm{mg} / \mathrm{kg})$ & $157.5 \pm 4.61^{\text {sc }}$ & $122.0 \pm 4.29^{\$ c}$ \\
\hline
\end{tabular}

Values were expressed as Mean \pm SEM of each group $(n=6)$ and were significant when done One-way ANOVA with Tukey's post hoc test. '*' $p<0.001$ when compared with normal, ' $\$$ ' $p<0.001$ with positive control, ' $a$ ' $p<0.001$ with standard. 


\begin{tabular}{|c|c|c|c|c|c|c|}
\hline Treatment & $\begin{array}{c}\text { AchE } \\
\text { activity (OD } \\
\text { value/mg } \\
\text { protein) }\end{array}$ & $\begin{array}{l}\text { Protein } \\
\text { activity } \\
(\mathrm{mg} / \mathrm{g})\end{array}$ & $\begin{array}{c}\text { Lipid } \\
\text { peroxidation } \\
\text { (MDA) } \\
\text { (nmole } / \mathrm{mg} \\
\text { protein) }\end{array}$ & $\begin{array}{l}\text { SOD (units/ } \\
\text { mg protein) }\end{array}$ & $\begin{array}{l}\text { Catalase ( } \mu \mathrm{mol} \\
\mathrm{H}_{2} \mathrm{O}_{2} / \mathrm{min} / \mathrm{mg} \\
\text { protein) }\end{array}$ & $\begin{array}{l}\text { Glutathione } \\
\text { reductase } \\
\text { (mole GSH/ } \\
\text { mg protein) }\end{array}$ \\
\hline Vehicle only & $0.34 \pm 0.003$ & $6.65 \pm 0.07$ & $110.69 \pm 0.014$ & $93.7 \pm 0.013$ & $97.3 \pm 0.351$ & $42.84 \pm 0.47$ \\
\hline $\begin{array}{c}\mathrm{AICl}_{3}(100 \mathrm{mg} / \\
\mathrm{kg})\end{array}$ & $0.04 \pm 0.02^{*}$ & $\begin{array}{l}11.46 \pm \\
0.13^{*}\end{array}$ & $222.40 \pm 0.018^{*}$ & $26.5 \pm 0.021^{*}$ & $25.05 \pm 0.01^{*}$ & $23.93 \pm 0.83^{*}$ \\
\hline $\begin{array}{c}\text { Rivastigmine } \\
(0.3 \mathrm{mg} / \mathrm{kg})\end{array}$ & $0.21 \pm 0.004^{\$}$ & $7.65 \pm 0.07^{\$}$ & $111.72 \pm 0.020^{\$}$ & $91.0 \pm 0.066^{\$}$ & $89.7 \pm 0.059^{\$}$ & $38.80 \pm 0.024^{\$}$ \\
\hline $\begin{array}{l}\text { CP leaf extract } \\
(200 \mathrm{mg} / \mathrm{kg})\end{array}$ & $0.13 \pm 0.02^{\$ a}$ & $\begin{array}{l}8.68 \pm \\
0.06^{\text {sa }}\end{array}$ & $150.2 \pm 0.012^{\$ a}$ & $82.6 \pm 0.023^{\$ a}$ & $74.9 \pm 0.088^{\$ a}$ & $27.78 \pm 0.66^{\$ a}$ \\
\hline $\begin{array}{c}\text { CP leaf extract } \\
(400 \mathrm{mg} / \mathrm{kg})\end{array}$ & $0.24 \pm 0.01^{\mathrm{sc}}$ & $\begin{array}{l}8.05 \pm \\
0.09^{\$ c}\end{array}$ & $115.4 \pm 0.019^{\$ c}$ & $91.8 \pm 0.042^{\$ c}$ & $91.9 \pm 0.063^{\$ c}$ & $34.82 \pm 0.64^{\mathrm{Sc}}$ \\
\hline
\end{tabular}

Values were expressed as Mean \pm SEM of each group $(n=6)$ and were significant when done One-way ANOVA with Tukey's post hoc test. '*' $p<0.001$ when compared with normal, ' $\$$ ' $p<0.001$ with positive control, ' $a$ ' $p<0.001$ with standard.

choline toxin where it gains high affinity to transferrin expressed in the blood brain barrier. Upon entering the brain, it induces inflammatory responses, slows down axonal transport, inhibits long term potentiation, causes structural abnormalities there by causing decrease in levels of acetylcholine at the synaptic cleft. ${ }^{16}$

Rivastigmine was used as a standard drug as it the only proven pharmacological therapy for symptomatic treatment of $\mathrm{AD} .{ }^{17}$ Treatment of $\mathrm{AD}$ rats with rivastigmine as a protective agent led to an improvement in the oxidative stress as represented by significant increase in acetylcholine levels as well as improves results in behavioural and biochemical parameters when compared with $\mathrm{AD}$ induced diseased rats.

\section{Histopathological Results of Brain}

Aluminium chloride induced (positive control) rats showed significant increase in amyloid plaques in the cortex of the brain when compared to normal control $\left({ }^{*}<0.05\right)$, standard and $C P$ leaf extract $(200 \mathrm{mg} /$ $\mathrm{kg})\left({ }^{\$ a} p<0.05\right)$ treated rats. Rivastigmine and test drug (Carica papaya leaf) showed results that were confirmed by the histopathological findings of brain tissues, where in amyloid plaques that are formed from $\mathrm{AlCl}_{3}$ administration disappeared in treated rats when compared to diseased rats (Figure 1).

The efficacy of rivastigmine in the treatment of dementia, where it binds to AChE molecule in the precursor if Ach in irreversible manner. Carica papaya leaf extract also inhibits amyloid formation by directly inhibiting $A \beta$ aggregation, metal chelation, antioxidant property, hypocholesterolemic effect, modulating-secretase activity, anti-inflammatory property and modulating the JNK signalling pathways. All these effects may also contribute to its neuroprotective effect. This also explains the fact that aluminium chloride treatment caused a marked reduction in the acetylcholinesterase activity which was restored by chronic papaya leaf treatment. The hippocampus and Dentate Gyrus (DG) of brain are mainly responsible for memory formation. ${ }^{18}$ This could be the only mechanistic pathways for the neuroprotective effect of Carica papaya leaf in cognitive dysfunction of aluminium chloride treated rats. Pre-treatment with Carica papaya leaf significantly reverted the $\mathrm{AlCl}_{3}$ induced changes in rats. The extract used proved to have neuroprotection as an evidence from improvement in the neurological score of Acetyl cholinesterase, lipid per-
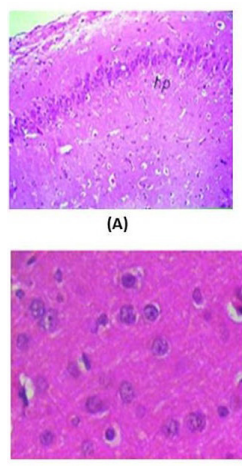

(D)

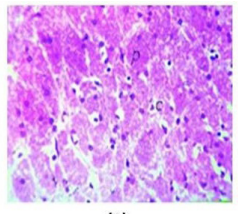

(B)

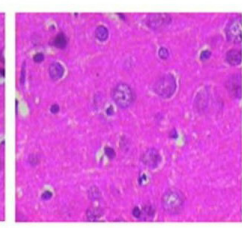

(E)

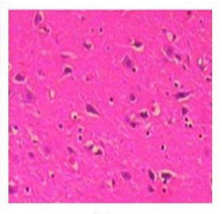

(c)

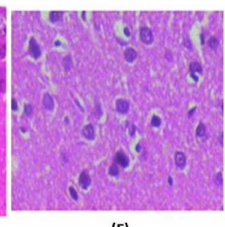

(F)
Figure 1: Histopathology Results of Brain. (A) Normal control animal (group I) showing normal histological structure of hippocampus; (B) Positive controlled group (group II) showing plaque in hippocampus; (C) Rats given $\mathrm{AICl}_{3}$ without any treatment showing neurofibrillary tangles. (D) Animal treated with rivastigmine $(0.3 \mathrm{mg} / \mathrm{kg})+\mathrm{AlCl}_{3}$ for 20 days as a protection against $A D$, showing neurons i.e more or less like normal group; (E) Animal treated with $\mathrm{AlCl}_{3}+200 \mathrm{mg} / \mathrm{kg}$ of CP leaf extract for 42 days as a protection against $A D$, showing neurons i.e. more or less like normal group; (F) Animal treated with $\mathrm{AlCl}_{3}+400 \mathrm{mg} / \mathrm{kg}$ of $\mathrm{CP}$ leaf extract for 42 days as a protection against $A D$, showing neurons i.e. more or less like normal group. 
oxidation, glutathione, catalase, glutathione reductase, SOD, protein. This may be attributing to the presence of flavonoids, alkaloids, steroids, tannins and minerals of Carica papaya leaf.

\section{CONCLUSION}

The present study indicates the cumulative protective effect of Carica papaya leaf with high level of antioxidant activity against $\mathrm{AlCl}_{3}$ induced spatial memory deficit and further confirms the beneficial effect of antioxidants in neurodegenerative disorder such as AD. Thus, it might be concluded that Carica papaya leaf, through its antioxidant potential, provided neuroprotection against $\mathrm{AlCl}_{3}$ induced cognitive deficits and oxidative damage in rats. Further warrants the need for molecular studies to elucidate the mechanisms underlying the protective effects of Carica papaya leaf for Alzheimer's disease.

\section{ACKNOWLEDGEMENT}

Authors acknowledge sincere thanks to the management for the facilities granted for the research work.

\section{CONFLICT OF INTEREST}

The authors declare no conflict of interest.

\section{ABBREVIATIONS}

AchE: Acetyl Cholinesterase; MDA: Malondialdehyde; SOD: Super Oxide Dismutase; GR: Glutathione Reductase; ANOVA: Analysis of variance; DNA: Deoxy Ribo Nucleic Acid; DTNB reagent: 5,5'-dithiobis(2-nitrobenzoic acid); IAEC: Institutional Animal Ethics Committee; CPCSEA: Committee for the Purpose of Control and Supervision of Experiments on Animals; rpm: Rotation Per Minute; ITL: Initial Transfer Latency; CP: Carica papaya; RTL: Retention Latencies; TBARS: Thiobarbituric Acid Reactive Substances; AD: Alzheimer's Disease; DG: Dentate Gyrus; JNK: c-Jun $\mathbf{N}$ : Terminal Kinase; $\mathbf{A l C l}_{3}$ : Aluminium chloride.

\section{REFERENCES}

1. Brook MR, Johnson E, Ziegler-Graham K, Arrighi MH. Forecasting the global burden of Alzheimer's disease. Alzheimer's And Dementia. 2007;3(3):186-91.

2. Bharathi P, Shamasundar NM, Sathyanarayana RTS, Naidu MD, Ravid R, Rao KSJ. A new insight on Al-maltolate-treated aged rabbits as Alzheimer's animal model. Brain Res Rev. 2006;52(2):275-92.

3. Nisar A, Hina F. Dengue fever treatment with Carica papaya leaf extract. Asian Pacific Journal of Tropical Biomedicine. 2011;1(4):330-3.

4. Onaku LO, Attama AA. Antagonistic anti-malarial property of Carica papaya leaf extracts in combination with Artesunic acid in Plasmodiam berghei infected mice. Journal of Vector Borne Diseases. 2011;48(2):96-100.

5. Giordano R, Costantini S. Some aspects related to the presence of aluminium in waters. Ann Ist Super Sanità. 1993;29(2):305-11.

6. Bjertness E, Candy JM, Torvik A, Ince P, McArthur F, Taylor GA, et al. Content of brain aluminium is not elevated in Alzheimer's disease. Alzheimer Dis Assoc Disord. 1996;10(3):171-4.

7. Khandelwal KR. Practical Pharmacognosy Techniques and Experiments: Pune. Nirali Prakashan. 2004.

8. Léonard T, Paul DDD, Théophile D, Emmanuel AA, Selestin NS, JeanFrançois $\mathrm{F}$, et al. Acute and sobchronic toxicity of Anacardium occidentale leaves hexane extract in mice. African Journal of Traditional, Complementary and Alternative Medicines. 2007;4(2):140-7.

9. Carageorgiou H, Sideris AC, Messari I, Liakou Cl, Tsakiris S. The effects of rivastigmine plus selegiline on brain acetylcholinesterase, ( $\mathrm{Na}$ ) ATPase activities, antioxidant status and learning performance of aged rats. Neuropsychiatr Dis Treat. 2008;4(4):687-99.

10. McLachlan DR, Bergeron C, Smith JE, Boomer D, Rifat SL. Risk for neuropathologically confirmed Alzheimer's disease and residual aluminum in municipal drinking water employing weighted residential histories. Neurol. 1996;46(2):401-5.

11. Krewski D, Yokel RA, Nieboer E, Borchelt D, Joshua CJ, Harry J, et al. Human health risk assessment for aluminium, aluminium oxide and aluminium hydroxide. J Toxicol Environ Health B Crit Rev. 2007;10(1):1-269.

12. Kawahara M, Muramoto K, Kobayashi K, Mori H, Kuroda Y. Aluminium promotes the aggregation of Alzheimer's -amyloid protein in vitro. Biochem Biophys Res Commun. 1994;198(2):531-5.

13. Ellman GL, Courtney KD, Andres V, Featherstone RM. A new and rapid colorimetric determination of acetylcholinesterase activity. Biochem Pharmacol. 1961;7(2):88-95.

14. Globus MY, Alonsa O, Dietrich WD, Busto R, Ginesberg MD. Glutamate release and free radical production following brain injury effect on post traumatic hypothermia. J Nuero Chem. 1995;65(4):1704-11.

15. Halliwell B. Reactive oxygen species in living system: Source Biochemistry and role in human disease. AM J Med. 1991;99(3C):145-22.

16. Dringen R. Metabolism and functions of brain. Progress in Neurobiol. 2000;62(6):649-71.

17. Barati P, Shamsundar NM, Satyanarayanarao TS, Naidu MD, Ravid R, Rao KSJ. A new insight on Al-maltolate treated rabbits as Alzheimer's model. Brain Res Rev. 2006;52(2):275-92.

18. Xia CK, Yokel RA. Aluminium facilitation of iron mediated lipid peroxidation is independent on $\mathrm{pH}$ substartye, Aluminium and Iron concentration. Arch Biochembiophys. 1996;327(2):222-6.

\section{SUMMARY}

The neuroprotective effect of Carica papaya leaves was evaluated in albino rats by aluminium chloride induced neurotoxicity model. Various behavioural, biochemical and histopathological parameters were estimated in aluminium exposed animals. Chronic aluminium administration resulted in significant motor incoordination and memory deficits, which were also endorsed biochemically as there was increased oxidative stress as well as elevated Acetylcholinesterase (AChE) and aluminium levels in the brain. Pre-treatment with alcoholic extract of Carica papaya leaves in aluminium exposed animals significantly improved muscle coordination and memory deficits as well as reduced oxidative stress, AChE and decreased abnormal aluminium deposition in the brain. Histopathological findings showed significant increase in amyloid plaques in the cortex of the brain treated with alcoholic extract of Carica papaya leaves. The extract used proved to have neuroprotection as an evidence from improvement in the neurological score of Acetyl cholinesterase, lipid peroxidation, glutathione, catalase, glutathione reductase, SOD, protein. This may be attributing to the presence of flavonoids, alkaloids, steroids, tannins and minerals of Carica papaya leaf. 


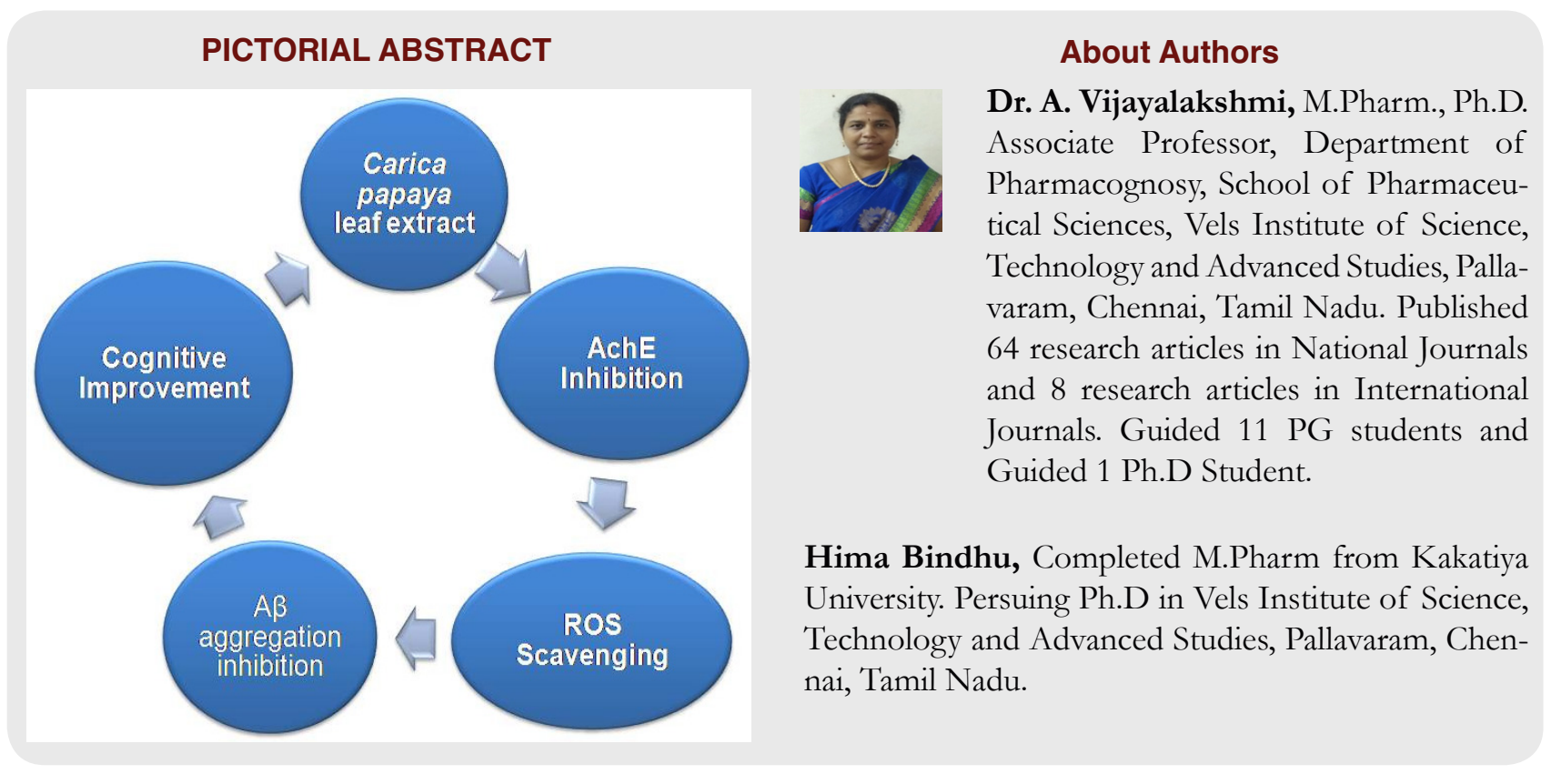

Cite this article: Bindhu KH, Vijayalakshmi A. Neuroprotective Effect of Carica papaya Leaf Extract against Aluminium Toxicity: An Experimental Study on Cognitive Dysfunction and Biochemical Alterations in Rats. Indian $\mathrm{J}$ of Pharmaceutical Education and Research. 2019;53(3 Suppl 2):s392-s398. 